\title{
The Somali Civil War: Integrating Traditional and Modern Peacebuilding Approaches
}

\author{
Israel Nyaburi Nyadera and Mohamed Salah Ahmed
}

\begin{abstract}
This study seeks to assess how the conflict in Somalia has transformed over the years and examines the merits of adopting a hybrid approach to peacebuilding. The article argues that given the changes experienced in the conflict and the sociopolitical and cultural characteristics of the Somali Society, a hybrid peace strategy which combines the traditional Xeer approach and contemporary counter-terrorism strategies can fill the gaps previous peace efforts failed to achieve. This approach has the potential to re-establish the horizontal and vertical social contracts between the people themselves and with the government which had been lost prior to and during the conflict.
\end{abstract}

Keywords Somalia, peacebuilding, conflict resolution, counter-terrorism

\section{Introduction}

As the armed conflict in Somalia continue to have a devastating toll on the citizens' lives, a series of droughts that have resulted in famine and humanitarian crisis have only made the situation worse. The double tragedy has left domestic and international actors strained on how to address the situation in Somalia. Individuals and institutions involved in crafting potential peace strategies are facing serious challenges as new issues which affect the nature and intensity of the conflict continue to emerge. For nearly three decades, the armed conflict has rapidly changed from a civil war to war against terrorism, piracy, human trafficking, economic crimes, transnational attacks as well as refugee crisis. It has also led to the disintegration of socio-economic and political fabrics of the once promising Horn of Africa country. Unending peace efforts by scholars, states and non-state actors have yet to yield sustainable peace. Even when a transitional government was established, it still lacked control and legitimacy across the whole territory of Somalia. To understand how the country reached such dangerous levels, it is important to examine the origin of the conflict. 
Table 1. Top Ten Most Fragile Countries in 2019

\begin{tabular}{l|c|c|c|c|c|c|c|c|c|c|c|c|c|c}
\hline \hline Countries & Rank & Total & SA & FE & GG & EC & UD & HF & SL & PS & HR & DP & RD & EX \\
\hline Yemen & 1st & 112.4 & 9.7 & 10.0 & 9.7 & 7.8 & 7.0 & 9.9 & 9.5 & 10.0 & 9.8 & 9.7 & 10.0 & 9.4 \\
\hline Somalia & 2nd & 110.9 & 9.8 & 10.0 & 8.6 & 9.4 & 8.9 & 8.9 & 9.1 & 9.0 & 10.0 & 9.1 & 9.0 & 9.1 \\
\hline South Sudan & 3rd & 110.8 & 9.4 & 9.7 & 9.1 & 9.2 & 6.8 & 9.9 & 9.5 & 9.0 & 9.5 & 9.7 & 9.5 & 9.5 \\
\hline Syria & 4th & 110.7 & 9.9 & 9.9 & 10.0 & 7.2 & 8.4 & 10.0 & 9.1 & 10.0 & 7.6 & 10.0 & 10.0 & 8.7 \\
\hline Congo, D.R. & 5th & 109.4 & 8.5 & 9.8 & 9.7 & 8.6 & 6.9 & 9.7 & 9.5 & 9.5 & 9.8 & 10.0 & 9.4 & 8.0 \\
\hline $\begin{array}{l}\text { Central African } \\
\text { Republic }\end{array}$ & 6th & 107.5 & 8.3 & 9.7 & 8.0 & 9.9 & 6.8 & 8.9 & 10.0 & 9.2 & 8.8 & 10.0 & 9.5 & 8.4 \\
\hline Chad & 7th & 106.4 & 9.2 & 9.5 & 8.3 & 8.9 & 8.4 & 9.3 & 9.4 & 8.5 & 9.6 & 9.2 & 7.7 & 8.5 \\
\hline Sudan & 8th & 104.8 & 8.4 & 9.4 & 9.4 & 8.0 & 8.0 & 9.3 & 8.3 & 8.9 & 9.1 & 9.3 & 8.6 & 8.1 \\
\hline Afghanistan & 9th & 102.9 & 9.9 & 8.9 & 7.5 & 7.7 & 7.5 & 9.0 & 9.5 & 7.6 & 9.0 & 9.3 & 8.6 & 8.3 \\
\hline Zimbabwe & 10th & 99.2 & 8.5 & 10.0 & 6.4 & 7.6 & 7.0 & 9.1 & 8.7 & 8.3 & 9.3 & 8.5 & 7.2 & 8.6 \\
\hline
\end{tabular}

Source: Fragile States Index (Fund for Peace 2019)

Note: SA - Security Apparatus, FE - Factionalized Elite, GG - Group Grievance, EC - Economic Decline, UD - Uneven Development, HF - Human Flight and Brain Drain, SL - State Legitimacy, PS - Public Services, HR - Human Rights \& Rule of Law, DP - Demographic Pressure, RD - Refugees \& IDPs (internally displaced persons), EX - External Intervention

Historians consider deep-rooted factors that culminated in Siad Barre ascending to power through a military coup as the origin of the crisis being witnessed in Somalia. Siad Barre is blamed for being a catalyst to the war as his actions in trying to consolidate power after the 1969 coup only accelerated the country towards disaster. Barre and his cronies began to rule the country as if it were their personal enterprise. Siad Barre's presidency is seen as formulating a brutal dictatorship, violating human rights, and demonstrating systematic discrimination of other clans (Ingiriis 2016, 167-215). These combined with an ambitious, yet ill-thought foreign policy resulted in the emergence of domestic clan-based movements and external forces that were reluctant to support Barre's regime. Confrontation between the government and a coalition of clanbased forces such as the 'Somali National Movement' and the 'Somali Salvation Democratic Front' weakened the government internally and led to the overthrow of Said Barre in 1991 (Nyadera, Ahmed and Agwanda 2019).

The absence of a functioning central government created a state of anarchy and placed the young nation at the mercy of different factions which began to violently scramble for control of state assets both in the urban centers and in the rural areas. Events that surround the months between March 1991 and August 1992 led to the displacement of over 1.5 million people and left an estimated 25,000 others dead (Bradbury and Healy 2010, 10). Three decades ago, those who 
witnessed the disintegration of the state described it as burbur (a Somali word meaning 'catastrophe'). It is difficult to declare the catastrophe has ended as most citizens continue to experience uncertainty and constant threat to their security. The unchanged situation is captured by the Failed State Index where Somalia was the most fragile country consecutively between 2008 and 2011 (Daniels 2012; Hansen 2013; Makinda 1993). Between 2011 and 2019, Somalia has been the second most fragile state after Yemen.

The Fragile States Index not only shows that the country has struggled to recover from the events of 1991, but also how difficult peacebuilding has been. Early peace efforts began in 1992 and continued through to 1995. During this period, the United Nations (UN) Security Council passed Resolution 733 and Resolution 746 that established the United Nations Operation in Somalia I (UNISOM I) and later, Resolution 794 which established the Unified Task Force (UNITAF). The former was to deal with peacekeeping operations while the latter was tasked to respond to the humanitarian crisis that had caused an estimated loss of lives of over 300,000 citizens to war and severe famine in 1991-92 (Muravchik 2005, 26-30). At first, the presence of the UN peacekeeping troops operating under the UNISOM I and UNITAF were welcomed by the locals. However, when unprovoked attacks against the Pakistani troops under the UNISOM II on July 5, 1993 led to the death of over ten soldiers, relations between the peacekeepers and the locals deteriorated. This change of attitude, together with other factors such as the growing insecurity for aid workers, the shooting down of the American Black Hawk helicopter, and insufficient funds led to the withdrawal of UN troops and aid workers on March 3, 1995.

With the UN not willing to continue its commitments in the Somali after suffering casualties during the previous peace operations, the distrust of foreign actors, particularly the United States, by Somalis and the inability of regional bodies to solve the conflict, Ismail Omar Guelleh, the Djibouti president, and a few African and Arab states took the initiative, organizing five peace conferences between 1996 and 2006. Meanwhile, several regions in Somalia such as Somaliland and Puntland began to declare either independence or autonomy-a move that has since become a serious hindrance to peace efforts (Rýdlová 2007, 62; Ingiriis 2018, 9; Magan 2016, 36; Brons 2001; Drysdale 1992). Efforts spearheaded by the international actors in 2005 to try and form a state in Somalia that are yet to achieve their objective of bringing lasting peace, stability, and reducing the threat of armed non-state actors including the radical Islamists groups. In fact, the activities of armed groups have intensified in the last decade posing a threat to the regional and international security. In 2017 , the UN estimated over 500,000 people have died due to the conflict and over 3 million others have been displaced. Even more concerning is the rise in the number of actors and nature of threats to Somali's security since 2005 as seen in the figure below. 
Figure 1. Nature and Number of Conflicts in Somalia between 1998 and 2020

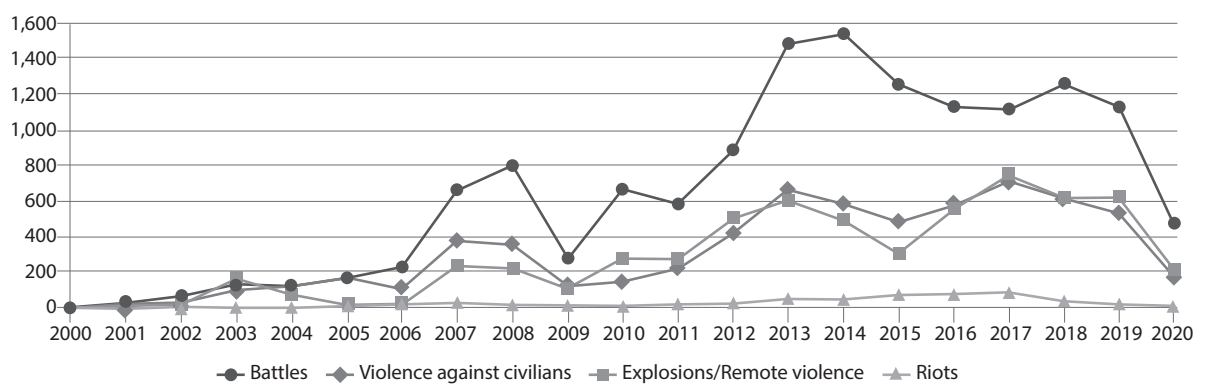

Source: Armed Conflict Location \& Event Data Project (ACLED) (2020)

Given the failure of previous peace efforts, most of which were top-bottom, foreign-driven and government formation oriented, this article seeks to examine an approach that remains unexplored. The study focuses on the past peace efforts in order to outline some of the weaknesses which reduced their chances of success. It also examines previous peace approaches used by the indigenous Somali communities to solve disputes among themselves and combines these approaches with contemporary strategies to propose a hybrid peacebuilding approach that may have an impact in the Somali case.

\section{Traditional Peace Approaches and the Current Crisis}

Conflict among the Somali clans are not new and can be traced back to the precolonial era. However, the colonial administrative system of divide-and-rule as well as the post-independence winner-takes-all majoritarian political system seems to have worsened the rivalry among the clans in many African countries (Kisaka and Nyadera 2019; Nyadera and Bincof 2019; Nyadera 2018). Historically, regular feuds and disputes were mainly sparked by conflict over resources such as water, camel, and grazing locations (Salwe 1996, 10; Elmi and Barise 2006, 33). Salwe $(1996,10)$ opines that under such circumstances, revenge amongst the clans was regular alongside the struggle for resources. To regulate the conflicts in the absense of legal courts and constitution at the time, the Xeer system, a traditional approach to solving conflict was established to mediate between the belligerent parties and restore peace (Elmi and Barise 2006, 33). One area of note, while the pre-colonial pastoralist conflicts are similar to what is being experienced in the country today, these traditional practices offer valuable lessons and practices that are relevant in the contemporary situation (Compagnon 1992, 11).

The implementation of the indirect rule by the British enabled its administrative officers to govern the territory by appointing chiefs or clan leaders (Salwe 1996, 5; Rýdlová 2007, 25). This weakened and reduced the influence of 
the traditional system of Diya-paying groups. The Akils system was chosen as a replacement for the now ineffective Xeer system. The Akils system empowered a single person with the authority to administer law and order within the clan, carrying out colonial administration's rules and regulations, bringing to justice those who committed crimes within the clan (Lewis 1961, 201).

The chief was chosen because of his loyalty to the clan and colonial administration which created competition and rivalry among the clans to obtain this position. This was the first impact of the divide-and-rule policy towards Somalis which has remained effective even to today (Salwe 1996, 5). However, on the other hand, this also marks the beginning of structural conflict where the clan feuds and conflicts were institutionalized and structuralized. As Galtung $(1969,167)$ asserts, structural violence, unlike personal or direct violence, is invisible as it does not require the existence of an active violence in the structure where someone harms another, but, the structure itself is the violence and enables inequality of power and life (Ho 2007, 4).

After Somalia got its independence in 1960, Somalia was united, and urbanization grew rapidly, extensively changing the types of resource as well as the means of obtaining them. Domination of the state institutions became the ultimate option to control the nation's resource. Traditional resources such as water, camel, and pasture were replaced with more sophisticated means whereby access to government resources, foreign aid, and recruiting more civil servants from home community had become the conflict sources (Ingiriis 2018; Elmi and Barise 2006, 34). In other words, post-colonial state formation fueled the structural conflict in Somalia which, in turn, created more confrontations and problems. Despite the civil government and the rising transformation into more democratic culture, the impact of the structural violence inherited from the colonial administration became clearly evident a year after the post-colonial state creation when young commanders from Northern Somali attempted a coupe d'état. The motivation behind the coupe d'état was mostly due to the frustrations with the political power-sharing and their desire to declare independence in the Republic of Somalia (former Italian colony) (Laitin and Samatar 1987). As the frustration, dissatisfaction and displeasure continued, another coup d'état led by Said Barre took place in 1969 following the assassination of the president by one of the presidential guards in Laascanood. This marked the end of democracy and a multiparty system in Somalia (Samatar 2002; Rýdlová 2007, 40).

The political and economic policies such as terrorizing and exploiting citizens, severe socialization of the economy, and little public service delivery in return, makes a case for Barre's regime to be considered as a completely predatory state. Nevertheless, according to Evans $(1995,45)$ the predatory state is one that "preys its citizen, terrorizing them, despoiling their common patrimony, and providing little in the ways of service in return." From the intellectual standpoint, the term predation seems a critical ingredient and has two dimensions: good, 
which is associated with developmental state; and, bad predation, associated with predatory states (Reno 2015, 732). Despite the poor economic situation, political leaders of predatory states pursue antithetical developmental policies to maximize available resources and avoid any policies that could improve the welfare of their citizens and bring a political change that would challenge their power and survival. Barre's regime followed this path as the regime's behavior towards political opposition, the welfare of the citizens, and the economic development policies were austere and harsh. This predatory state attitude had sparked off the emergence of clan insurgence militia and firmly caused the collapse of the military regime in 1991.

Despite all the political and economic achievements in the first course of the military regime, things changed dramatically in 1977 after Siad Barre regime lost the war against Ethiopia, cut relations with the Soviet Union, and witnessed the emergence of various armed rebels (Laitin and Samatar 1987, 80). As the military regime lost the faith and confidence of the public, the regime started to use, once again, the clan systems as a shield to stay in power (Rýdlová 2007, 46; Laitin and Samatar 1987, 93). As this grew structurally, in 1991 it eventually turned into a direct violence when the state collapsed completely. It is estimated that 300,000 people died as the result of either disease, starvation, or civil war in the first year. Struggle for power and government control were the main causes of the civil war. Not only were the clan warlords fighting for the power, but other Islamists militias such as Al-Ittihad al-Islamiyah emerged seeking power although they were not very effective (Brons 2001, 219-20; Rýdlová 2007, 62).

Various peace and reconciliation initiatives took place, but none of them succeeded or produced an inclusive mechanism that could bind Somalis together and bring back the trust and confidence among the Somalis community. As a matter of fact, as part of the conflict transformation, the Islamic Court Union (ICU) was created in 2006 with much support from the business and public communities in Mogadishu with the goal to oust the warlords controlling in Mogadishu. The ICU later transformed into the Alliance for the Restoration of Peace and Counterterrorism backed by the United States and thereby turning the conflict and violence in Somalia into the war on terror (Ingiriis 2018, 10).

The ICU was finally ousted by the Ethiopian troops and Transitional Federal Government army at the time led by Abdullahi Yusuf. Since then, the conflict has been a war on terror when Al-Shabaab which has been operating secretly within the ICU administrative structure but came out later after the ICU was defeated. The lack of quality and trust in the Somali police and the Transitional Federal Government allowed Al-Shabaab to grow and reach ungoverned spaces. In 2009, despite controlling a large territory, Al-Shabaab later lost this stronghold. However, Al-Shabaab operations in Somalia have exemplified the opportunities for violence in the context of a weak state whereby the weak state and insurgents compete for legitimacy and economic resources to obtain their political and 
Figure 2. Al-Shabab Attacks between July 2017 and January 2018

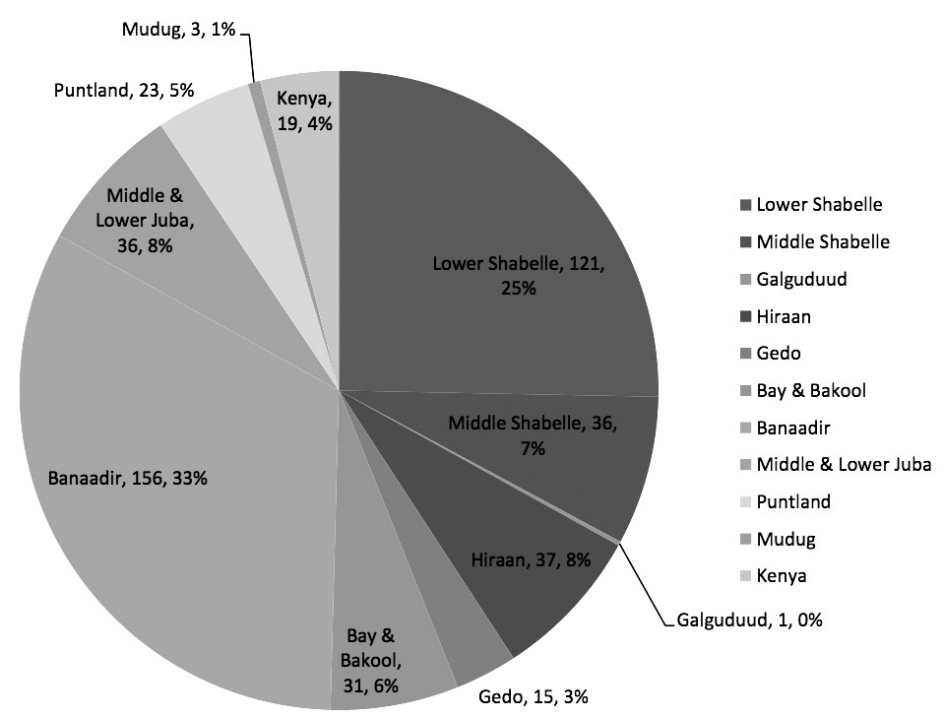

Source: Anzalone (2018)

strategic interests (Eisenstadt 1973). Nevertheless, Al-Shabaab has become a regional security threat where they effectively carry out attacks on neighboring countries such as Westgate attack and Garissa University in Kenya.

The ongoing political and social crisis exposed during the last three decades raises critical questions over the effectiveness of some of the existing peacebuilding strategies. Why does this conflict keep transforming from one form to another? Even with new political structure and system, the conflict has turned into clan-border conflicts as in the case of Puntland and Galmudug, or Puntland and Somaliland. The inclusion of grassroots elements for social reconciliation into the peacebuilding efforts is very much needed to end the conflict and avoid turning into the current conflict into, yet again, another form of conflict.

\section{Unending Peace Efforts}

The prolonged conflict in Somalia has not gone unnoticed as it has attracted the attention of local, regional, and international actors who have embarked on several efforts to broker peace among the warring parties. Nonetheless, all these efforts have largely failed in providing permanent peace as the violence continues. Such failure of these efforts has been explained by several potential causes which include (1) the top-down approach that does not include the people, (2) the failure of all these agreements to address the major causes of the conflict, and (3) 
their inability to provide deals that all involved parties feel satisfied with. In the end, the peace efforts have been marred by mistrust and lack of agreeable terms among the parties. Among these peace efforts are the Djibouti Peace Conference, Cairo Peace Conference, Arta Peace Conference, and Mbagathi Peace Conference. However, the most notable common factor of all these peace processes was their similar failure; they have largely been unsuccessful in providing permanent and sustainable peace to the worsening and prolonged Somali conflict.

The Djibouti Peace Conference was initiated by the President of Djibouti in 1991. The goal was to bring together rival factions and try to convince them to agree on a peace deal. One faction was led by General Aideed and the other led by General Ali Mahdi. It is estimated that by the time this conference was being organised in 1991, approximately 14,000 people had been killed and 42,000 others maimed during to the conflict (Lewis 2003, 264). Key regional and international actors endorsed the Djibouti peace initiative financially and technically as means to simultaneously pursue their own geopolitical and foreign policy interests (Lyons and Samatar 2010, 29). Conclusively, the Djibouti Peace Conference lacked validity within both the confines of Somalia and the larger international community. The Djibouti process lacked the aegis from Somalis who were polarized by their clan militia affiliations (Bercovitch et al. 2008, 54; Touval and Zartman 1985).

After the Djibouti Peace Conference failed in 1991, another peace process was initiated this time by the UN under the leadership of Secretary-General Boutros Boutros-Ghali. This conference was hosted in Ethiopia in 1993 and adopted the name Addis Ababa Conference. With the hope of achieving permanent and sustainable solutions this time, the conference was bestowed the title theme of "National Reconciliation" (Lewis 2010). Critics say the failure of this peace initiative could have been sowed from the beginning and the biggest obstacle, which later proved to be the catalyst for the failure of the conference, was the process of selecting delegates to the conference which caused a disagreement between the UN, who had the key role in facilitating this peace initiative, and the factional leaders. General Aideed who through his militia controlled the largest part of the country was excluded from the selection of the delegates. In turn, only fifteen militia groups signed the peace agreement that saw the creation of the Transitional National Authority. The Transitional National Authority did not last long as the Addis Ababa mediation failed to address the root causes of the conflict. The absence of a proper framework for the implementation of the outcome of the peace initiative became a detrimental shortcoming of the process. Consequently, the Transitional National Authority failed to provide a comprehensive way to deter the militia groups from further engaging in conflict and, most importantly, to accomplish an inclusive disarmament which would have been one of the most important outcomes of the conference (ibid., 132).

Despite the failure of these two peace initiatives, the efforts to foster 
peace among the factional warlords in Somalia continued and regional and international actors sustained their commitments to achieve peace in Somalia. In the wake of this, the Cairo Peace Conference took place in 1997 and was attended by twenty-eight warlords and other factional leaders under the patronage of the governments of Egypt, Libya, and Yemen. These warlords and factional leaders aligned themselves into two umbrella coalitions that included, firstly, the Somali Salvation Alliance led by Ali Mahdi comprised of fifteen factions and backed by the Ethiopian government and, secondly, the Somali National Alliance consisting of thirteen factions led by Hussein Mohammed Aideed, who replaced his father after he was killed, and backed by Libya (Elmi and Barise 2006, 40).

The main goal of the Cairo Conference was to reform the collapsed central government with the hope that it could bring law and order in the country. As the peace talks progressed the decision as to which form and type of government Somalia would institute arose, which led to a stalemate in the negotiations and, especially, by the international community eventually resulting in the complete collapse of the peace talks. Following the collapse of previous peace efforts and three years after the last peace dialogue, Arta peace conference took place in 2000 in Djibouti hosted by Djiboutian President Omar Guelleh. Despite enormous efforts and a gigantic delegation invited by the Djibouti President, the legitimacy of the Arta process was challenged even before its implementation. These challenges to legitimacy later led the Arta peace talks down the same road that previous peace efforts took, resulting in failure. However, in 2004 Intergovernmental Authority on Development initiated and sponsored the Mbagathi peace talks but once again failed to offer any tangible solution to the Somali conflict and put an end to the prolonged conflict. Mukhtar (2007) argues that the process repeated the same major mistake that failed all previous peace attempts, which was the lack of a sustainable framework for tranquillity and reconciliation before the institutionalization of a central government. The Mbagathi process was however unfortunately undermined by the sustained insistence on clan formula representation in the process. The outcomes of the Mbagathi peace process, within which clan identity has transformed into a pillar for the elevation of individual political ambitions, accompanied by the perception of ethnic benefits thereby, embedding ethnicity and ethnic conflict to political, economic, social, cultural, or territorial issues between two or more ethnic communities (Brown 2001, 211).

\section{Discussion and Recommendations}

Failed peacebuilding efforts are not unique to Somalia, especially in the last decade following the outbreak of the Arab Spring which affected a number of countries in the Middle East and North Africa. Attempts to forge peace in Libya, 
Yemen, Syria, and South Sudan have not resulted in sustainable peace (Nyadera and Kisaka 2020). In this section, in order to develop a comprehensive proposal for potential peacebuilding approach, we will derive lessons from the five previous attempts which brought the warring parties in Somalia to the negotiating table in search for peace. The first critique of previous peace attempts that becomes clear with the mention of five failed peace efforts is that the solution to the crisis in Somalia will require a more ambitious, robust and inclusive plan that will need to be implemented in short, medium- and long-term phases.

Additionally, previous peace efforts seem to have overlooked the significance of two important aspects of the conflict. One is that the conflict has transformed into a complex mixture of traces of the post-1991 civil war on the one hand and a series of organized criminal activities which are embedded into the chaos. Such transformation means that peace efforts will need to satisfactorily address the root causes of the civil war while simultaneously provide solutions that will eliminate criminal activities such as terrorism, secession movements, piracy as well as trafficking. Below are some of the proposed strategies for the Somali conflict which seek to address one form of challenge or another.

\section{National Dialogue}

The first strategy is the national dialogue approach. The national dialogue has been a strategy of choice in solving conflicts of differing natures and in different countries globally. Although the most recent cases of national dialogue in Tunisia and Yemen which took place between 2013 and 2014 may have had mixed results, it helps to recognize that this approach is plausible and can have an effective impact on the Somali Conflict. The national dialogue will give the people of Somalia a unique opportunity to address some of the most pertinent issues that have affected the country for over three decades. This approach is important because it is aligned with the traditional Xeer practice that was used by Somali clans to solve disputes through consensus building in the past. In this new push, the composition and process of the national dialogue will slightly change to accommodate new actors and ideas and overcome previous obstacles to peace efforts. To begin with, national dialogue would have to be held on Somali territory which will be a deviation from previous efforts. Based on this perspective, we propose a three-tier approach where delegates will be engaged at the regional level, sub-regional level and national level. The objective of the national dialogue will be to address fundamental issues of political and economic reforms. Specifically, areas for discussion could include the new structure of government, the role of religion in public spaces, resource sharing, independent institutions, national ethos, truth and reconciliation, the place of regional governments in the new dispensation, Somali identity among others.

This national dialogue is expected to lay the foundation for a new constitution that will also be a tool of conflict resolution. Several studies have 
suggested that constitutions can be formative foundation for transforming or solving conflicts (Hart 2001; Widner 2005; Roper 2004; Mamdani 2018). According to Kuperman (2015), a cleverly designed constitution can go a long way in reducing or even ending conflicts of different forms. He proposes either an accommodative or integration constitutional model both with distinct features for managing tension among different groups in the country. We recommend the accommodation constitutional model because it seeks to guarantee various groups of their social, geographical and political rights. This model often offers alternatives such as federalism, proportional representation, equity in resource sharing or autonomy. Therefore, the end product of this inclusive, nationwide national dialogue will be the culmination of a new constitution.

The main significance of the national dialogue method is that it will create a symbolic two-dimensional social contract between the people and the state and between the people among themselves. The underlying assertion is that the consequences and burden of continuous war have been felt by Somalis of different ages and socioeconomic status. This means that time has come for the citizens through the national dialogue to acknowledge and respect the other clans and agree on a Somali-first agenda rather than pursuing individual clan interests whose impact over the last three decades has been full of destruction and suffering. Agreement through the national dialogue to forge peace and give room to state-building will be the horizontal social contract. On the other hand, the new constitution that will be drafted from the suggestions given by the delegates will elaborate on the relationship between the government and the people through clearly defined mandates and term limits.

We propose the creation of a layer within the government structure that will consist of a specified number of clan elders to be selected through a rigorous process and who will remain above political and partisan attachments to act as a bridge between the people and the government of selected issues that may require constant discussion and consensus. The traditional legitimacy of local authorities in the past made it possible for the local chiefs to encourage their followers to comply with the rules and regulations of the government which in turn provided for the protection of the local chief thus creating what Marx Weber (1964) refers to as a legal-rational state. Even after independence, most Africans are strongly tied to the authority of their traditional leaders and, conversely, simply attached to the state in a legal sense. This is evident in the manner voting is done during national elections whereby members of a particular clan or ethnicity will vote for candidates to whom local leaders have demonstrated their support. Such influence will be useful in bridging the gap between the people and the government. However, aware of the previous shortcomings of national dialogues in countries like Yemen in 2015, we recommend a number of principles to be religiously observed during the process.

The first principle should be the inclusion of a diverse and broad base of 
Table 2. Institutions for National Dialogue Resolution Implementation

\begin{tabular}{c|l|l}
\hline \hline & \multicolumn{1}{|c|}{ Subject } & Time Orientation \\
\hline 1 & Establishing a Truth Justice and Reconciliation Commission & Medium Term \\
\hline 2 & Establishing an Independent Commission on Constitution Review & Medium Term \\
\hline 3 & Establishing an Independent Boundaries Review Commission & Medium Term \\
\hline 4 & Establishing an Independent Office of the Ombudsman & Long Term \\
\hline 5 & Establishing an Independent Police Oversight Authority & Long Term \\
\hline 6 & Establishing a Judicial Review Commission & Medium Term \\
\hline 7 & $\begin{array}{l}\text { Establishing the National Dialogue implementation Oversight } \\
\text { Authority }\end{array}$ & Medium Term \\
\hline
\end{tabular}

Source: Based on author's assessment.

stakeholders with the aim of maximizing the national dialogue's potential of identifying and dealing with the root causes of the conflict. We recommend that the traditionally excluded members of the society who were not part of previous peace initiatives such as youths, women, professionals, diaspora representatives, cultural and religious leaders need to be included. The selection of these representatives will need to be through a rigorous, transparent, and inclusive process in order for the approach to be considered genuine and trustworthy.

Secondly, the national dialogue will need a credible conveyer. This will not only dilute any thoughts of bias or potential short play, but it will attract a wide base of participants to the national dialogue. The success in Senegal and Tunisian dialogues are attributed to the involvement of highly distinguished and respected conveyers. For the case of Somalia, the conveyors could be a local or international organization, groups of people or even an individual such as the Turkish President Recep Tayyip Erdogan or the Emir of Qatar both of who enjoy massive support among the locals.

The third principle is continuous public participation and transparency. This is important because even an already convened national dialogue process may lose traction if the public considers the proceedings opaque and detached from the local dialogue. The successful national dialogue witnessed in Senegal in 2009 involved collecting the opinion of citizens from each district in the country as well as those in the diaspora.

The fourth principle is clarity of the mandate and appropriate terms of reference, rules, and procedures. Majority of national dialogues are conducted without the involvement of formal government institutions due to reasons ranging from lack of capacity, legitimacy or total absence of a central government. In turn, this means that the national dialogue will have to operate under its own sets of procedures and rules. More importantly, a good national dialogue will have provisions on how arguments and deadlocks will be swiftly and effectively 
dealt with should they occur. Such procedures are at the core of the peace process as they include timelines and establishment of critical caretaker institutions as well as approval of binding resolutions. Therefore, rules and terms of reference must be respected at all time.

The fifth principle is to have clear implementation mechanism of the resolutions. Having agreed on the issues to be addressed, it is important to also develop a mechanism through which these issues will be implemented. We recommend the following institutions be established to assist with the implementation of the national dialogue resolutions.

\section{Counter-Terrorism and Organized Crime}

We propose a second strategy that will focus on disrupting the activities of criminal gangs and terrorist groups in Somalia. Indeed, the line separating the civil war and criminal activities have increasingly become blurry and there is a need to address such lawlessness as part of the peace process. The threat these groups pose on the eventual peace in Somalia cannot be underestimated. First, they pose a serious threat to the state-building as their presence continues to discourage investment which is required to elevate the millions of young people from poverty. Secondly, some of these groups including Al Shabab appear to have their own political idea of how Somalia should be governed. The problem with these groups is that they are not willing to allow divergent opinion and this means involving them in the national dialogue is extremely difficult. Already piracy and terrorist groups operating inside Somalia have proved capable of causing significant security threat in the country and the region as a whole. The presence of armed non-state actors in the country can reduce the gains made by the national dialogue. We, therefore, consider the following measures important in dealing with organized crime in Somalia.

\section{Counterterrorism Measures}

Terrorist groups in Somalia have proved more than once to be elusive and lethal in avoiding operations against them. Even the ongoing operations by African Union Mission in Somalia (AMISOM) supported by the United States has not yielded the desired outcome. We, therefore, suggest a change not only of the strategy but also of the objectives of the forces involved. One we seek to propose is a mixed approach of force and other non-lethal methods. A first contact operation that will be characterized by the creation of safe zones in advance for civilians to relocate before a massive military campaign is launched in the areas under control of terrorist groups. The objective is to ensure the groups' fightingwill is broken and their capability to continue launching attacks are destroyed. The operations to capture territory taken by the Islamic State in Iraq and Syria can be a point of reference since the group and these countries are similar to the case in Somalia. Such an operation is massive and will need the support of 
international and regional actors to achieve. Capturing the territories and putting them under control of formal forces and institutions will be important. Some of the principles guiding this operation can include (1) identifying the group's positions and destroying them, (2) disrupting their organizational and logistics systems through intense pressure, (3) identifying local collaborators and provide needed support to them, and (4) disrupting external support.

Apart from the intense military campaign, local political and civilian support should be attracted as well as the support of religious authorities. Before the operation is launched, there are a number of questions that will have to be addressed. These include the likelihood of success risk of acting or not acting, local and international legitimacy on the operation, countries' willingness to provide troops, the impact on civilians as well as how the groups will respond to the operation will all need to be assessed.

\section{Cut Funding and Access to Military Hardware}

When the African Union launched a massive operation under AMISOM in 2007 to defeat the terrorists in Somalia, a lot of people were hopeful that this would be the beginning of peace in the country. More than twelve years later, Al Shabab and other terrorist groups are actively involved in carrying out attacks in major cities of Somalia and neighbouring countries. This has been attributed to the availability of funds within the $\mathrm{Al} \mathrm{Shabab}$ terrorist group, which has been used to carry out the group's operations and to purchase the weapons to carry out attacks or repel AMISOM troops. Therefore, cutting financial and military support to this group needs to be prioritized. Several reports indicate that some regional and international states are providing financial support to Al Shabab. For example, Eritrea has been adversely mentioned even by the UN report (Wezeman 2010). The transitional government also repeatedly mentioned Syria, Iran, Qatar, and Yemen for providing support to these groups (Kambere 2012, 40-43). Equally, Saudi Arabia has been mentioned as a financier of the terrorist organization through its Salafi groups support initiative (Dorsey 2012). Apart from the state sponsors, Al Shabab is said to be receiving significant support from the charity organizations, other terrorist groups and individual donations from different countries across the world. Somalis in the diaspora are also a major source of funding to the group (Vilkko 2011; Menkhaus 2009, 87). The port of Kismayo was a strategic source of revenue for the group with UN reports estimating an annual revenue of USD \$35-50 million. However even after the port came under the control of the Kenyan army, there is an allegation of continued smuggling of charcoal and sugar through the same port. We recommend more attention to the strategies these groups are using to avoid detection by international financial controls. Piracy and extorting money from innocent civilians through illegal taxation is also another source. This means shedding light on activities that appear to be routine as well as strengthening the banking sectors. Proper 
policing of the borders even if it means targeting Al Shabab controlled the border territories as a priority.

\section{Disarmament and Rehabilitation}

Disarmament and rehabilitation are important stages of peacebuilding (Ferreira et al. 2007, 32; Daboh et al. 2010, 7) There needs to be an agreed approach on how the armed groups will be disarmed with voluntary disarmament given priority. Apart from disarmament, reintegration and demobilization efforts need to be given a proper consideration. Based on our assessment, failure to address these issues during the previous peace efforts may have left numerous loopholes that led to their failure. We are aware that the process of disarmament is not only sensitive but also can be very difficult. This is why there is a need to gain the trust of the actors involved as well as creating an environment of transparency and fairness. Amnesty will be an important element of the process to encourage voluntary disarmament.

Additionally, we are proposing a rehabilitation process for the young people who were part of the groups as well as assistance with reintegration into society. This is a long-term process that will need commitment and dedication of the people within and outside of the country. There should be guarantees provided to ensure everyone to feel safe in the country. Armed groups elsewhere have been transformed and reintegrated into the society as exemplified in the cases of Northern Ireland, Rwanda, Colombia, and Iraq; therefore, it is possible that such transformation can be achieved in the Somali case as well. Safe zones created during the counter-terrorism operation can be the first point for the rehabilitation process.

\section{Truth Justice and Reconciliation Approach}

Given the complexity of the crisis in Somalia, a well-structured, inclusive and transparent truth, justice, and reconciliation program will have to be part of the peacebuilding process. In fact, the framework through which this will be done will have to be agreed upon during the national dialogue process. Similar approaches have been implemented successfully in several countries on the African continent such as South Africa, Rwanda, and Kenya and its effectiveness can therefore not be overlooked (Sarkin 2000; Rotberg 2000; Fischer 2011). Necessary institutions will need to be established so as to implement the program effectively. However, such an initiative may face political, financial, institutional challenges and shortage of skilled personnel which can be avoided through proper planning and collaboration. 


\section{Conclusion}

The crisis in Somalia has been overstretched to the extent that it significantly continues to test the resilience and repertoires of those keen on restoring peace to Somalia. Indeed, the protracted period of war in Somalia is one that few consultants, academicians, donors or international organizations providing strategies and models of peace have lived through. Most of the previous recommendations have been attempting to establish a central government based on the assumption of the Treaty of Westphalia of 1648 (Leonard and Samantar 2011). While this approach has in some cases prevented some states from a complete collapse, in Somalia, it has failed to offer a sustainable solution to the crisis as well as enabling successful political, social and economic reforms. It is true that the absence of a stable government in Somalia has resulted in Hobbes's description of the state of nature which is "nasty, brutish and short" (Hobbes 1651; Button 2008). However, after over six attempts to establish a central government, it is clear that following a long period of conflict an instability forming a government translates to peace. Conversely, Beichman (2008) and Winter (2004) seem to agree that when a government collapses, the social contract between the people and the government is also dissolved.

Hurried efforts to form a government that rewards the perpetrators of the conflict and isolates public participation are therefore not an effective means to achieve peace. Countries such as Zaire (today Congo) and Somalia have suffered almost a similar fate as the central authorities in these countries lost claim of obedience from the members of the society (Etzioni 1964; Turner 1985). This is why we recommend a robust and ambitious initiative that may take more time but has the potential to bring sustainable peace. The two broad strategies namely the national dialogue and the counter-terrorism and organized crime seek to achieve very important goals. One of them is that they will create a conducive environment whereby a new constitution that is inclusive and establishes strong institutions will trigger a new set of social contracts between the people among themselves and between the people and the government. The objective is to restore a society of tolerance, trust on the public institutions, rule of law and a government that lives up to a non-partisan role of providing public goods effectively.

Gellner (1983, 6-7) in his definition of a nation argues that "two men are of the same nation if and only if they recognize each other as belonging to the same nation." Gellner gives further insight into the potential weakness of establishing a state without consulting members of the community. In other words, members of the community must be ready to recognize that other individuals also have equal rights to live and be part of society. The extent of socio-political, cultural, and economic discrimination among communities in Somalia can be attributed to weak institutions, clan-based politics and a lack of national ethos. Achieving 
peace amidst grievances from different quarters of the society, especially those who feel discriminated, has been a serious obstacle to peace. Therefore, we argue that the reconstruction of the Somali state will need to be factored in the community contract and not only in a contract between the people and the state.

We acknowledge that various challenges that face modern African societies such as clanism, corruption, economic classes as well as the scarcity of resources and opportunities will continue to threaten peacebuilding in Somalia. We, therefore, call upon the people to raise up beyond mere individual and clan identity and look at the potential the country has in building a stronger society for the generations to come. The violence witnessed so far does not benefit the majority; instead, peace has a greater ability to help millions of Somalis realize their full potential. Other bigger and more dangerous conflicts have been resolved across the world and it is time the people of Somalia take their future into their own hands by supporting the national dialogue and counter-terrorism initiatives and bring peace to the Horn of Africa. The cultural practice of Xeer and Diyapaying is a sufficient proof that the people of Somalia have tangible historical lessons to use in organizing and promoting a national dialogue.

\section{References}

Anzalone, Christopher. 2018. "Black Banners in Somalia: The State of al-Shabaab's Territorial Insurgency and the Specter of the Islamic State." CTC Sentinel 11 (3): 1218.

Armed Conflict Location \& Event Data Project (ACLED). 2020. Nature and Number of Conflict Events in Somalia between 1998 and 2019. ACLED. https://acleddata.com/ dashboard/\#/dashboard/8E1709F031CEEA016215F7EED4C567E3 (accessed May 25, 2020).

Beichman, Arnold. 2008. "Troubled Nations. Hobbesian World." Washington Times, October 16.

Bercovitch, Jacob, Victor Kremenyuk, and I. William Zartman, eds. 2008. The SAGE Handbook of Conflict Resolution. Thousand Oaks, CA: SAGE Publications.

Bradbury, Mark, and Sally Healy, eds. 2010. "Endless War: A Brief History of the Somali Conflict." London: Conciliation Resources. https://www.c-r.org/accord/somalia/ endless-war-brief-history-somali-conflict (accessed May 14, 2020).

Brons, Maria H. 2001. Society, Security, Sovereignty and the State in Somalia: From Statelessness to Statelessness? University of Michigan: International Books.

Brown, Michael E. 2001. "Ethnic and Internal Conflicts: Causes and Implications." In Turbulent Peace: The Challenges of Managing International Conflict, eds. Chester A. Crocker, Fen Osler Hampson, and Pamela R. Aall. Washington, DC: USIP Press.

Button, Mark E. 2008. Contract, Culture, and Citizenship, Transformative Liberalism from Hobbes to Rawls. University Park, PA: Penn State Press.

Compagnon, Daniel. 1992. "Political Decay in Somalia: From Personal Rule to Warlordism." Refuge: Canada's Journal on Refugees 12 (5): 8-13. 
Daboh, Fodeba, Sahr Fatoma, and Michael Kuch. 2010. "Disarmament, Demobilization Rehabilitation and Reintegration (DDRR): A Case Study of Liberia, Sierra Leone, and South Sudan." New York Science Journal 3 (6): 6-19.

Daniels, Christopher L. 2012. Somali Piracy and Terrorism in the Horn of Africa. Lanham, MD: Scarecrow Press.

Dorsey, James M. 2012. "Saudi Arabia Embraces Salafism: Countering the Arab Uprising." Fair Observer, February 27. http://www.fairobserver.com/ article/saudi-arabiaembraces-salafism-countering-arab-uprising (accessed on January 12, 2019).

Drysdale, John Gordon Stewart. 1992. Somaliland 1991: Report and Reference. Hove: Global-Stats.

Eisenstadt, Shmuel Noah. 1973. Traditional Patrimonialism and Modern Neopatrimonialism (Vol. 1). Beverly Hills, CA: Sage Publications.

Elmi, Afyare Abdi, and Abdullahi Barise. 2006. "The Somali Conflict, Root Causes, Obstacles, and Peace-Building Strategies." African Security Studies 15 (1): 32-54.

Etzioni, A. 1964. Modern Organizations. Englewood Cliffs, NJ: Prentice-Hall.

Evans, Peter 1995. Embedded Autonomy, States, and Industrial Transformation. Princeton, NJ: Princeton University Press.

Ferreira, Rialize, Abraham Sewonet Abatneh, and Ian Liebenberg. 2007. "Disarmament, Demobilisation, Rehabilitation and Reintegration of Rwandan Child Soldiers." Commonwealth Youth and Development 5 (2): 32-50.

Fischer, Martina. 2011. "Transitional Justice and Reconciliation, Theory and Practice." In Advancing Conflict Transformation, The Berghof Handbook II, eds. B. Austin, M. Fischer, and H. J. Giessmann. Opladen, Farmington Hills: Barbara Budrich Publishers.

Fund for Peace. 2019. “Fragile States Index 2019.” https://fundforpeace.org/2019/04/10/ fragile-states-index-2019 (accessed May 14, 2020).

Galtung, Johan. 1969. "Violence, Peace, and Peace Research.” Journal of Peace Research 6 (3): 167-91.

Gellner, Ernest. 1983. Nations and Nationalism. Ithaca, NY: Cornell Press.

Hansen, Stig Jarle. 2013. Al-Shabaab in Somalia: The History and Ideology of a Militant Islamist Group. Oxford: Oxford University Press.

Hart, Vivien. 2001. "Constitution-making and the Transformation of Conflict." Peace \& Change 26 (2): 153-76.

Ho, Kathleen. 2007. "Structural Violence as a Human Rights Violation." Essex Human Rights Review 4 (1): 1-17.

Hobbes, Thomas. 1651. Leviathan (Longman Library of Primary Sources in Philosophy). New York, NY: Routledge. https://socialsciences.mcmaster.ca/econ/ugcm/3ll3/ hobbes/Leviathan.pdf (accessed April 24, 2020).

Ingiriis, Mohamed Haji. 2016. The Suicidal State in Somalia: The Rise and Fall of the Siad Barre Regime, 1969-1991. Lanham, MD: University Press of America.

Ingiriis, Mohamed Haji. 2018. "From Pre-Colonial Past to the Post-Colonial Present: The Contemporary Clan-Based Configurations of State building in Somalia." African Studies Review 61 (2): 55-77.

Kambere, Geoffrey. 2012. "Financing Al Shabaab: The Vital Port of Kismayo." Global Ecco 2 (3) 1-14.

Kisaka, Michael Otieno, and Israel Nyaburi Nyadera. 2019. "Ethnicity and Politics in 
Kenya’s Turbulent Path to Democracy and Development." Sosyal Siyaset Konferansları Dergisi 76 (2): 159-80.

Kuperman, Alan. 2015. “Obama's Libya Debacle: How a Well-meaning Intervention Ended in Failure.” Foreign Affairs 94 (2): 66-77.

Laitin, David D., and Said Samatar. 1987. Somalia: Nation in Search of a State. Boulder, CO: Westview.

Leonard, David K., and Mohamed S. Samantar. 2011. "What Does the Somali Experience Teach Us about the Social Contract and the State?" Development and Change 42 (2): 559-84.

Lewis, I. M. 2010. Making and Breaking States in Africa: The Somali Experience. New Jersey: Red Sea Press.

Lewis, Ioan M. 1961. A Pastoral Democracy: A Study of Pastoralism and Politics among the Northern Somali of the Horn of Africa. London: Oxford University Press.

Lewis, Ioan Myrddin. 2003. Ecstatic Religion: A Study of Shamanism and Spirit Possession, 3rd ed. London and New York: Routledge.

Lyons, Terrence, and Ahmed I. Samatar. 2010. Somalia: State Collapse, Multilateral Intervention, and Strategies for Political Reconstruction. Brookings Institution Press.

Magan, Abdi Ibrahim. 2016. "Somalia: Instability, Conflict, and Federalism." M.A. diss. Norwegian University of Life Sciences.

Makinda, Samuel M. 1993. Seeking Peace from Chaos: Humanitarian Intervention in Somalia. Lynne Rienner.

Mamdani, Mahmood. 2018. Citizen and Subject: Contemporary Africa and the Legacy of Late Colonialism. Princeton, NJ: Princeton University Press.

Menkhaus, Ken. 2009. "African Diasporas, Diasporas in Africa, and Terrorist Threats." In The Radicalization of Diasporas and Terrorism. ETH Zurich (Vol. 229), eds. Bruce Hoffman, William Rosenau, Andrew J. Curiel, and Doron Zimmermann. Rand Corporation.

Mukhtar, Mohamed H. 2007. "Somali Reconciliation Conferences: The Unbeaten Track." In Somalia at the Crossroads: Challenges and Perspectives in Reconstituting a Failed State, ed. A. A. Osman. London: Adonis \& Abbey Publishers Ltd., 123-30.

Muravchik, Joshua. 2005. The Future of the United Nations: Understanding the Past to Chart a Way Forward. Washington, DC: AEI Press.

Nyadera, Israel Nyaburi. 2018. "South Sudan Conflict from 2013 to 2018: Rethinking the Causes, Situation and Solutions." African Journal on Conflict Resolution 18 (2): 59-86.

Nyadera, Israel Nyaburi, Mohamed Salah Ahmed, and Billy Agwanda. 2019. "Transformation of the Somali Civil-War and Reflections for a Social Contract Peacebuilding Process." Gaziantep University Journal of Social Sciences 18 (4): 1346-66.

Nyadera, Israel Nyaburi, and Mohamed Omar Bincof. 2019. "Human Security, Terrorism, and Counterterrorism: Boko Haram and the Taliban." International Journal on World Peace 36 (1): 4-15.

Nyadera, Israel Nyaburi, and Michael Otieno Kisaka. 2020. "Contemporary Conflicts, Cross-border Military Operations, and the Declining Role of the UN: The Case of Turkey and Saudi Arabia." Digest of Middle East Studies 29 (1): 1-12. https://doi. org/10.1111/dome.12206.

Reno, William. 2015. "Predatory States and State Transformation.” In the Oxford Handbook of Transformations of the State, eds. Stephan et al. Oxford: Oxford University Press. 
Roper, Steven D. 2004. "Federalization and Constitution-making as an Instrument of Conflict Resolution." Demokratizatsiya 12 (4): 527-39.

Rotberg, Robert I. 2000. "Truth Commissions and the Provision of Truth, Justice, and Reconciliation." In Truth V. Justice: The Morality of Truth Commissions, eds. Robert I. Rotberg, and Dennis Thompson. Princeton: Princeton University Press.

Rýdlová, Barbora. 2007. "Civil War in Somalia: A Colonial Legacy.” M.A. diss. Univerzita Karlova.

Salwe, Abdisalam Issa. 1996. The Collapse of the Somali State, the Impact of the Colonial Legacy. London: Haan.

Samatar, Ahmed I. 2002. "Somalia: Statelessness as Homelessness." The African State: Reconsiderations 19 (1): 217-51.

Sarkin, Jeremy. 2000. "Promoting Justice, Truth and Reconciliation in Transitional Societies: Evaluating Rwanda's Approach in the New Millennium of Using Community Based Gacaca Tribunals to Deal with the Past." Int'l LFD Int'l 2 (1): 112.

Touval, Saadia, and Ira William Zartman, eds. 1985. International Mediation in Theory and Practice. Boulder, CO: Westview.

Turner, Thomas. 1985. “Zaire: Stalemate and compromise." Current History (Pre-1986) 84 (1): $179-82$.

Vilkko, Valter. 2011. "Al-Shabaab: From External Support to Internal Extraction.” Ph.D. diss. Department of Peace and Conflict Research, Uppsala University.

Weber, Max. 1964. The Theory of Social and Economic Organization. New York: The Free Press.

Wezeman, Pieter. 2010. Arms Flows and the Conflict in Somalia. Stockholm: SIPRI. www. sipri.org/sites/default/files/files/misc/SIPRIBP1010b.pdf (accessed April 24, 2020).

Widner, Jennifer. 2005. "Constitution Writing and Conflict Resolution.” The Round Table 94 (381): 503-18.

Winter, Joseph. 2004. "Living in Somalia’s Anarchy." BBC News, November 18. http://news. bbc.co.uk/2/hi/africa/4017147.stm (accessed April 24, 2020).

Israel Nyaburi Nyadera is a Teaching Assistant at the department of Government and Public Administration, University of Macau and a graduate student at the Department of Political Science and Public Administration, Ankara Yildirim Beyazit University. He holds a master's in International Relations from the Middle East Technical University and a bachelor's degree in Political Science and History from the University of Nairobi. He has been a visiting researcher to the University of Milan. Email: inyadera@parliament.go.ke.

Mohamed Salah Ahmed is a Ph.D. candidate at the Department of Political Science and Public Administration, Ankara Yildirim Beyazit University. He holds a master's in Political Science and Public Administration from the Political Science and Public Administration and a bachelor's degree in Political Development Studies from the University of Bosaso. Email: 185206403@ybu.edu.tr. 